\title{
NOTAS HISTORIOGRÁFICAS DOS POEMAS DE VICTOR HUGO TRADUZIDOS NO BRASIL
}

\author{
Dennys da Silva Reis \\ Jocileide da Costa Silva
}

\section{Introdução}

L'un des deux yeux du poète est pour l'humanité, l'autre pour la nature. Le premier de ces yeux s'appelle l'observation, le second s'appelle l'imagination.

De ce double regard toujours fixé sur son double objet naît au fond du cerveau du poète cette inspiration une et multiple, simple et complexe, qu'on nomme le génie. (Hugo, Les Rayons et les Ombres)

Nascido em 1802, Victor Hugo é um representante do século XIX por seu numeroso e importante trabalho intelectual e também por ter vivido mais de oitenta anos desse século, fato quase impossível para o período, visto que muitas enfermidades ainda não tinham cura, e a expectativa de vida da sociedade europeia da segunda metade do Oitocentismo era de quarenta anos. Anatole France (apud Leão, 1960, p. 8), em comemoração ao centenário do nascimento de Victor Hugo, dedicou as seguintes palavras ao escritor:

Aquele a quem saudamos aqui com respeito não é apenas um homem, é um século da França e da humanidade, é o século dezenove do qual Victor Hugo exprimiu melhor do que ninguém, os sonhos, as ilusões, os erros, as previsões, os amores, os ódios, os receios e as esperanças... ${ }^{1}$ (grifo nosso)

Sua criação artística também se realizou durante praticamente todo o século XIX: na literatura teve seus primeiros escritos produzidos no segundo decênio, no ano de 1812, com duas peças teatrais, L'Enfer sur terre e Le Château au diable, das quais se têm apenas fragmentos. Pode-se dizer que Hugo foi para a literatura o que Mozart foi para a música, um prodígio que muito influenciou outros literatos.

\footnotetext{
${ }^{1}$ Tradução de Carneiro Leão. No original: “Ce que nous saluons ici avec respect, ce n'est pas seulement un homme, c'est un siècle de la France et de l'humanité, ce dix-neuvième siècle de la France dont Victor Hugo exprima plus abondamment que tout autre les songes, les illusions, les erreurs, les divinations, les amours et les haînes, les craintes et les espérances..."
} 
Artista múltiplo, engajado na vida política e nos acontecimentos de sua época, Victor Hugo tornou-se conhecido no Brasil ainda em vida. Muitas de suas obras foram lidas em francês e muitas foram traduzidas já no século XIX. Sua impactante influência no Brasil não se deu apenas nas artes, mas também nos ideais políticos de sua contemporaneidade.

As obras literárias que se tornaram mais conhecidas no Brasil até os dias atuais são os romances Notre-Dame de Paris, mais difundido com o título O corcunda de NotreDame, e Os miseráveis (Les misérables). Porém, a obra de Hugo abrange também inúmeras peças teatrais não muito conhecidas pelos brasileiros, assim como uma vasta produção poética.

Neste artigo, buscamos realizar um apanhado histórico das traduções dos poemas desse escritor realizadas no Brasil, desde o século XIX até a atualidade, a fim de levantarmos o maior número possível das traduções feitas.

Sabendo que abranger a totalidade é uma pretensão audaciosa, intitulamos o trabalho de "Notas historiográficas dos poemas de Victor Hugo traduzidos no Brasil", pois é um apanhado do que foi possível encontrar até o momento em periódicos, livros e outros meios de divulgação. É importante ressaltar, portanto, que muito ainda poderá ser descoberto.

Procuramos estabelecer um mapeamento crítico das traduções dos poemas de Victor Hugo para compreender essa produção intelectual no Brasil a partir do século XIX. Para isso, nossas notas são referenciadas pelo viés da historiografia, que é

um processo epistemológico e espelha a produção intelectual de um certo momento do passado. Ela é um fragmento para compreendermos - numa preocupação de totalidade esse passado. Na historiografia estão os anseios de uma época, as verdades que a dinâmica social das ideias desfigurará com o passar do tempo [sic] (Torres, 1996, p. 56).

Assim, com o levantamento proposto, tentamos compreender as escolhas realizadas pelos tradutores do século XIX até as últimas traduções dos poemas de Hugo que foram produzidas recentemente.

Ainda no tocante à historiografia, Michel de Certeau (1982, p. 66) afirma que "toda pesquisa historiográfica se articula com um lugar de produção socioeconômico, político e cultural. Implica um meio de elaboração circunscrito por determinações próprias: uma profissão liberal, um posto de observação ou de ensino, uma categoria de letrados, etc.” 
Nesse sentido, o levantamento aqui apresentado se caracteriza pelo interesse literário e tradutório que abrange a presente pesquisa e que pode contribuir para os estudos da obra de Victor Hugo no Brasil, assim como para os estudos da História da Tradução.

Estas notas historiográficas a respeito das traduções de poemas hugoanos foram elaboradas a partir do questionamento em latim Quid? (“o quê?”), estabelecido pelo estudioso Lieven D’Hulst (2001), ao propor uma análise historiográfica da tradução. Na tentativa de responder a esse questionamento, refletimos sobre o que se tem traduzido no Brasil e o que ainda não foi traduzido dos poemas de Hugo, de modo a salientar as possíveis razões de uma não tradução, assim como os temas priorizados pelos tradutores.

Examinamos, quando possível, quem são os tradutores dos poemas de Hugo e o que eles escreveram sobre a tarefa de traduzir a obra poética do escritor francês, verificando também o que há de crítica publicada sobre tais traduções.

Antes de mencionarmos as traduções de poemas hugoanos no Brasil, apresentamos algumas informações do autor como poeta.

\section{Victor Hugo, um poeta}

Madame, en ce jour si beau

Qui nous annonce un an nouveau,

Je vous souhaite de bonnes années,

Des jours de soie et d'or filés,

Et surtout en votre vieillesse

De bons enfants et des richesses.

Ainsi, madame, pour en finir, C'est avec bien du plaisir

Que je vous présente en ce jour

Et mon hommage et mon amour.

O poema acima, escrito em 1814, ou no fim de 1813 , de título “À madame la générale Lucotte pour le $1^{\text {er }}$ Janvier 1814" e assinado "Par son serviteur, Victor Hugo", é, segundo um dos biógrafos de Victor Hugo, Jean-Marc Hovasse (2001), o primeiro que se conservou do autor, pois muitos anteriores a este foram perdidos. No entanto, segundo sua filha Adèle Hugo (apud Juin, 1980, p. 232), os primeiros versos ditos por Victor Hugo foram: "Le grand Napoléon/ Combat comme un Lion". 
De todo modo, a primeira coletânea de poemas de Hugo publicada na França só apareceu no ano de 1822, com o título Odes et poésies diverses, que teve posteriormente quatro edições, a última datada de 1828 e publicada em dois volumes pela editora C. Gosselin e intitulada Odes et ballades. Outras antologias publicadas ainda durante o século XIX foram: Les orientales (1829, Paris); Les feuilles d'automne (1832, Paris); Les chants du crépuscule (1835, Paris); Les voix intérieures (1837, Paris); Les rayons et les ombres (1840, Paris); Les châtiments (1853, Bruxelas, Genebra e Nova Iorque; 1870, Paris); Les contemplations (1856, Bruxelas e Paris); La légende des siècles (1883-1884, Paris, edição definitiva, 4 vols.); Les chansons des rues et des bois (1866, Paris); L'année terrible (1872 e 1879?, Paris); L'art d'être grand-père (1877, Paris); Le pape (1878, Paris); La pitié suprême (1879, Paris); Religions et religions (1880, Paris); L'âne (1880, Paris); Les quatre vents de l'esprit (1881, Paris); La fin de Satan (1886, Paris); Dieu (1891, Paris); Toute la lyre (1893, Paris, edição difinitiva) ${ }^{2}$. Há ainda outras coletâneas publicadas na França como Océan, que contém versos produzidos a partir de 1815, porém muitos não estão datados; Les années funestes (1898) e Dernière gerbe, publicados em 1902.

O volume da produção poética de Victor Hugo é bem maior, pois também muitos de seus dramas foram escritos em versos. No entanto, como apontado anteriormente, este trabalho se detem no levantamento das traduções dos poemas hugoanos por tradutores brasileiros, não contemplando o teatro em verso.

Antes de iniciarmos as notas sobre as traduções brasileiras, salientamos alguns traços da obra poética de Victor Hugo. Não ambicionamos uma classificação dos poemas de Hugo, pois, segundo Henri Meschonnic (1977, p. 151), a obra do autor de Os miseráveis é caracterizada por uma continuidade que "é mais forte que qualquer linguagem dada. As formas de sua obra são mais fortes do que todas aquelas com as quais a aparência, a tradição e uma incompreensão variável as têm identificado. [...] [Sua] escrita expressa a visão do mundo". ${ }^{3}$

Essa continuidade está relacionada aos temas e até mesmo às obras literárias de Hugo, que dialogam entre si. Meschonnic nos apresenta um Hugo em que

\footnotetext{
${ }^{2}$ Essa classificação é baseada no livro Euvres poétiques complètes, de 1961.

${ }^{3}$ Tradução nossa. No original: “[...] est plus forte que tout langage. Les formes de son œuvre sont plus fortes que toutes celles auxquelles l'apparence, la tradition, et une incompéhension variable, les ont identifiées. [...] [Son] écriture émet la vision du monde.”
} 
tudo ali não são mais do que canteiros de obra: contemplação, Misérias, lenda e, a partir de 1843, castigos. A morte de sua filha e posteriormente o golpe de Estado colocaram um Norte em sua "forma meridional e precisa". A continuidade de Hugo, que atravessa os gêneros, atravessa também o tempo de sua obra ${ }^{4}$ (grifos do autor, p. 152).

Com isso, é certo dizer que a obra de Hugo é ainda atual porque nunca se dedicou apenas a temáticas de seu tempo, visto que, ao atravessar o tempo e mesmo o espaço francês, a continuidade presente na obra hugoana torna possível a atualidade e a universalidade de suas produções literárias.

Vale ressaltar também que Victor Hugo teve sua vida dividida a partir de um dos acontecimentos mais marcantes de sua história: o exílio. Com isso, ele distingue três momentos: o antes, o durante e o depois do exílio. Contudo, segundo Meschonnic (1977), tal divisão não apresenta uma ruptura da continuidade de sua obra, mas, para muitos estudiosos, esses três momentos marcam uma hierarquia da produção literária do autor, e que com tal divisão muitos priorizam certo período em detrimento de outro. No entanto, os poemas de Hugo, assim como suas obras literárias em geral, estão ligados a uma unidade "poético-profética, função política e funcionamento dessa linguagem"” (p. 14).

Em seu prefácio à Les rayons et les ombres, Victor Hugo descreve a tarefa de um "poeta completo" e delineia as características que suas criações devem englobar:

Em seus poemas ele colocaria os conselhos no tempo presente, os esboços sonhados do futuro; o reflexo, ora ofuscante, ora sinistro, dos acontecimentos contemporâneos; os panteões, os túmulos, as ruínas, as lembranças; a caridade para os pobres, a ternura para os miseráveis; as estações, o sol, os campos, o mar, as montanhas; os olhares furtivos no santuário da alma em que se percebem num altar misterioso, como pela porta entreaberta de uma capela, todas essas belas urnas de ouro, a fé, a esperança, a poesia, o amor; finalmente, ele colocaria nos poemas esta profunda pintura do eu que é talvez a obra mais importante, a mais geral e a mais universal que um pensador pode gerar $^{6}$ (Prefácio - Les rayons et les ombres; Hugo, 1961, p. 238).

\footnotetext{
${ }^{4}$ Tradução nossa. No original: “tout n'est alors chez lui que chantiers: contempaltion, Misères, légende, et dès 1843, châtiments. La mort de sa fille, puis le coup d'État et l'océan, mettront du Nord dans sa «forme méridionale et précise ». La continuité de Hugo qui traverse les genres, traversse aussi le temps de son œuvre".

${ }^{5}$ Tradução nossa. No original: "poétique-prophétique, fonction politique et fonctionnement de ce langage".

6 Tradução nossa. No original: "Dans ses poèmes il mettrait les conseils au temps présent, les esquisses rêveuses de l'avenir; le reflet, tantôt éblouissant, tantôt sinistre, des évènements contemporains; les panthéons, les tombeaux, les ruines, les souvenirs ; la charité pour les pauvres, la tendresse pour les misérables ; les saisons, le soleil, les champs, la mer, les montagnes; les coups d'œil furtifs dans le sanctuaire de l'âme où l'on aperçoit sur un autel mystérieux, comme par la porte entr'ouverte d'une chapelle, toutes ces belles urnes d'or,
} 
Victor Hugo evoca vários temas para resumi-los na "pintura do eu". Talvez seja esta maneira de fazer poesia a mais completa, pois o fazer poético envolve o singular e o geral, para que se possa alcançar o universal.

A universalidade da obra literária e os ideais de Victor Hugo atraíram muitos admiradores em todos os continentes. Os artistas e intelectuais brasileiros também se interessaram pela obra hugoana, visto que a presença da cultura francesa no Brasil durante o século XIX era marcante, somada ao importante prestígio do escritor no cenário político francês, assim como a seu gênio artístico.

Tal interesse culminou em inúmeras traduções. Romance, teatro e poesia, assim como correspondências foram objeto de tradução no Brasil já no século XIX. No século seguinte, outros textos importantes também já podiam ser encontrados em português, como prefácios, discursos, peças teatrais, novas traduções de seus romances, dentre outros. No século XXI, tradutores continuam prestigiando a atualidade da obra de Victor Hugo e levando ao público brasileiro novas traduções.

Vejamos brevemente a influência de Hugo no Brasil para que em seguida possamos discorrer sobre os poemas traduzidos.

\section{Victor Hugo no cenário brasileiro}

Victor Hugo influenciou inúmeros escritores brasileiro.s como Machado de Assis, Castro Alves, Gonçalves Dias e Gonçalves de Magalhães. Carneiro Leão, em sua obra Victor Hugo no Brasil, assinala que

No Brasil começou muito cedo a atração irresistível, a conformação em sua arte, com seus ideais.

Já em 1836 êle era comentado no Brasil por Pereira da Silva nas Variedades Literárias. Quando foi de seu exílio, então a repercussão em nossos meios intelectuais e sociais não teve limites (Leão, 1960, p. 37).

Essa "atração quase irresistível" se deu pelo tom provocador, pela originalidade e pela revolução trazida em sua prosa e em seus versos. Carneiro Leão levanta o

\footnotetext{
la foi, l'espérance, la poésie, l'amour ; enfin, il y mettrait cette profonde peinture du moi qui est peut-être
} l'œuvre la plus large, la plus générale et la plus universelle qu'un penseur puisse faire". 
questionamento: "Que poeta, que artista, naqueles tempos de ânsia de novidade não se apaixonaria pelo fascinante provocador dos conservadores e dos clássicos nas atitudes contundentes de um drama petardo?!” (p. 42). O romantismo no Brasil buscava o novo, a mudança e a liberdade. Por esses anseios, as artes e a política encontraram em Hugo um aliado importante.

A presença de Victor Hugo no Brasil não se manifestou apenas na literatura, mas igualmente na vida política dos brasileiros. Durante a luta pela libertação dos escravos, Victor Hugo foi um aliado dos abolicionistas ao se manifestar a favor deste processo.

O escritor também influenciou na arte musical, alguns maestros brasileiros se inspiraram em sua escrita literária para compor óperas, como Carlos Gomes com a ópera Maria Tudor (1879), Carlos Mesquita com La Esmeralda (1888), Gama Malcher com BugJargal (1890).

No que concerne a poema e música, também temos no Brasil composições musicais realizadas com base nos poemas de Hugo, como Les voix intérieures, do maestro Francisco Braga com partitura publicada em 1904, pela revista Kosmos; e no ano de 1914, Villa Lobos compõe a Op. 45, Les mères, cuja letra é originária do poema Les enfants, de Victor Hugo.

Tais traduções interartísticas ${ }^{7}$ também ilustram a importância da obra de Victor Hugo no Brasil. Mas essa relevância não permaneceu apenas no século XIX, pois “ele não escreveu apenas [para o seu século e] para seus concidadãos, mas para todos os cidadãos do mundo, porque ele não foi criado somente para seu tempo, mas para o futuro" (Laster, 2012, p. 36).

Como poeta visionário, artista além de seu tempo, Hugo continuou presente no século XX brasileiro, sobretudo graças à tradução de suas obras. No século XXI, sua obra ainda é atual e nos faz refletir sobre o fazer poético e temas presentes no cotidiano, como a exclusão social e a miséria. Essa continuidade e a universalidade de sua obra seguem despertando interesse, e as traduções fazem parte desse processo.

\footnotetext{
${ }^{7}$ Tradução Interartística é aqui concebido como a transmutação de uma arte para outra (do romance para cinema, do teatro para quadrinhos, etc).
} 
Nesse contexto, na busca por uma reposta do quê se tem traduzido da obra poética de Victor Hugo no Brasil, apresentamos como o autor, através de seus poemas, esteve e está presente no cenário literário brasileiro.

\section{Versões poéticas hugoanas no Brasil}

As primeiras traduções públicadas de poemas de Victor Hugo se deram ainda no século XIX nos mais diversos jornais brasileiros. É difícil precisar qual foi o primeiro periódico a publicar versões poéticas de Hugo devido à profusão de jornais existentes na época e à dificuldade de acesso e mapeamento de todos eles atualmente. Todavia, podemos mencionar alguns fatos relacionados a essas traduções poéticas.

Em primeiro lugar, as publicações dos poemas traduzidos nos revelam que era comum o fato de poetas serem tradutores da poesia hugoana, o que ainda atestamos na atualidade. Vejamos as seguintes notícias:

Deus invisível ao philosopho - é o titulo de um fragmento da «Legenda dos Séculos» de Victor Hugo, traduzida pelo ilustre poeta português Fernando Leal, com aquella graça e pureza de estylo que the conhece, que hoje publicamos na sessão litteraria (Gazeta do Norte, 21/01/1881).

[...] O nome de Raymundo Correia foi agora citado e exaltado pelo sr. Mayer Garção, a propósito de uma poesia de Victor Hugo, traduzida magistralmente, na forma e no sentimento, pelo autor do celebre soneto «As pombas» e dos primorosos sonetos á Luizinha, que enterneceram profundamente Eça de Queiroz (Correio do Brasil, $16 / 11 / 1903)$.

Essas notícias da Gazeta do Norte e do Correio do Brasil são apenas duas das várias existentes nos jornais brasileiros a informar que poetas tanto brasileiros quanto portugueses eram os responsáveis pelas traduções dos poemas hugoanos em solo nacional.

Em segundo lugar, os jornais brasileiros traziam, por vezes, notícias a respeito de poetas que traduziam, imitavam, parafraseavam ou mesmo plagiavam os poemas de Victor Hugo. A título de ilustração, podemos mencionar aqui dois casos: o primeiro está no periódico $O$ Mequetrefe e o segundo, no noticiário $O$ Imparcial.

Em $O$ Mequetrefe há uma entrevista entre dois poetas portugueses, um acusando o outro de plágio. Durante a entrevista, o poeta "plagiador" dá a seguinte resposta: 
Antes houvessem dito que eu imitei o ultimo verso d'aquella esplendida poesia de Victor Hugo: Passeando pela manhã, traduzida pelo Arthur:

A estrela d'onde vem? Para onde vae o cão?

Ah, sim, ha alguma aproximação de idéias, sem comtudo haver plágio, nem coisa que com isso se pareça. (O Mequetrefe, 10/10/1881)

Vemos neste primeiro exemplo que o poeta admite inspiração, aproximação ou mesmo influência da poesia hugoana sobre a sua própria. Afirmações como essas podemos encontrar correntemente no Diário do Maranhão e no Publicador Maranhense, dois periódicos que, muitas vezes, publicavam o poema do poeta brasileiro acompanhado do trecho do poema de Hugo (traduzido ou não) que lhe causou inspiração, as chamadas epígrafes.

Já no jornal $O$ Imparcial, de 15 de março de 1922, há uma grande reportagem na seção intitulada "Em legitima defesa" sobre o possível plágio que Vicente de Carvalho teria feito de um poema de Victor Hugo denominado Vieille chanson du jeune temps. Segundo Alberto Faria, Vicente de Carvalho teria traduzido o poema de Hugo e publicado em sua obra Ardentias com o título "Velha canção", se apropriando do poema, já que este não era tão conhecido à época. Em resposta, Vicente de Carvalho escreve o seguinte:

Nem é exacto que minha tradução, publicada nas Ardentias com título francez, Vieille chanson, e nunca reproduzida em qualquer outro dos meus livros, tivesse sido, como informa o Sr. Alberto Faria, incluída, como paráfrase e com o título Velha canção, nos Versos da Mocidade.

Ao organizar, muitos anos depois, e sobretudo com farrapos remendados dos livros que publicara em moço, o volume Versos da Mocidade, tentei corrigir a antiga e tosca traducção da Vieille chanson du jeune temps, traducção em que se sentia o desejo da fidelidade ao original, mas em que havia, entre outros muitos defeitos insuportáveis, rimas assim: voz e depois, Rosa e cousa. Do difficilimo trabalho de revisão a que a submeti, sahiu aquella poesia modificada por completo; deixou de ser a má traducção que primitivamente fora, para tornar-se simples paráfrase. Não me era licito, sem merecer a pécha de traddutore, tradditore, apresentar como traduzida, essa nova poesia, muito outra da Vieille chanson das Ardentias. Apresentei-a, com título Velha Canção, a pags. 23-25 dos Versos da Mocidade (Porto, Lello \& Irmão, editores, 1912) como imitada de Victor Hugo.

Confrontando-a, aqui, com a Vieille chanson du jeune temps, verificará o leitor que a Velha Canção, dos Versos da Mocidade, nem é uma traducção, que como tal se pudesse apresentar sem comprometer o traductor; nem é a Vieille chanson das Ardentias, traduzida literalmente, com escrupulosa preocupação de fidelidade ao original, estancia a estancia, verso a verso [...] (O Imparcial, 26/03/1922) (grifos do autor). 
Percebe-se, pela resposta de Vicente de Carvalho, uma apropriação do poema de Victor Hugo pela paráfrase e pela imitação, que para ele é diferente da tradução, pois, segundo suas palavras, a tradução está diretamente ligada a uma "escrupulosa preocupação de fidelidade". Disso se infere que, para Vicente de Carvalho, imitar ou parafrasear Hugo não é traduzi-lo; e que a preocupação demasiada com o original pode levar a produzir uma tradução tosca e defeituosa. Possivelmente essa seja uma das primeiras reflexões do que seja traduzir poemas hugoanos.

Por fim, no que tange aos jornais brasileiros (tanto os do século XIX, quanto os da metade de século XX), os responsáveis por esses periódicos eram os grandes formuladores e pesquisadores de opinião acerca do gosto popular no que concerne à poesia hugoana em francês ou traduzida no Brasil. Como exemplo disso, podemos citar o plebiscito poético do periódico El Correo Gallego, jornal publicado em língua espanhola no Rio de Janeiro na primeira década do século XX, que pedia aos seus leitores que escolhessem a melhor tradução da poesia La Tombe et la Rose de Victor Hugo:

De la bellísima poesía de Victor Hugo "La tombe et la rose", conocemos las cuatro traduccionees que damos á continuación y acerca de la cuales abrimos un pebliscito entre nuestros estimados subscritores á fin de que se sirvan mandarnos sus opiniones sobre la que les parezca ser mejor. [...]

Traducción de Nelson de Senna, poeta brasíleño [...]

Traducción de Gertrudes Gomez de Avellaneda, poetisa cubana. [...]

Traducción de Ricardo Carrasquilla, poeta colombiano. [...]

Traducción de Gutierres Coll, poeta venezolano [...]

Cada opinión deberá ser acompañada por una pequeña justificación de la traducción preferida. (El Correo Gallego, 04/06/1904)

Tal anúncio revela o apreço da poesia de Hugo nos jornais e também o quanto ela era, igualmente, traduzida por poetas brasileiros ou estrangeiros. Esse lugar da poesia hugoana nos jornais vai diminuir depois da década de 1940, para obter maior espaço nos livros.

Os primeiros livros que reúnem poemas hugoanos são algumas obras de autores brasileiros que traduziram um ou mais poemas de Hugo: Cantos (1857) de Gonçalves Dias, Obras completas de Casimiro de Abreu (1877), Flores transplantadas (1874) de Regueira Costa, Miosótis de Teixeira Melo (1877), Espumas flutuantes (1870) e Os escravos (1883) 
de Castro Alves, entre outros. Para além dessas publicações, a primeira obra de que temos conhecimento e que publicou somente poemas traduzidos de Hugo se intitula Hugonianas.

Hugonianas é uma obra organizada e idealizada por Múcio Teixeira ${ }^{8}$ em 1885 para homenagear o autor francês que tinha acabado de morrer. Segundo Teixeira,

A idéia que determinou o aparecimento deste livro não é original minha, por dois motivos:

Além de ser lembrada por meu amigo e primeiro romancista brasileiro da atualidade, Dr. ESCRAGNOLLE TAUNAY, com quem JOAQUIM SERRA e eu nos achávamos, na Livraria Faro \& Nunes, quando chegou a notícia do trepasso de VICTOR HUGO, nessa mesma ocasião, e a propósito disso, lembramo-nos de homenagem idêntica que, pouco depois do falecimento de LAMARTINE, foi consagrada à memória do sauvíssimo poeta do Jecelyn. Refiro-me às Lamartineanas, traduções também de poetas brasileiros, colecionadas pelo Dr. MACEDO SOARES.

Quanto à nítida edição elzeviriana, que faz honra aos prelos da Imprensa Nacional, não é permitido declarar o nome do magnânimo protetor das letras, sob cujos auspícios são impressas as Hugonianas. [...]

Compõe-se este volume de 55 versões extraídas de vários livros ou jornais, e 51 traduções expressamente feitas para a minha coleção de Hugonianas (Teixeira, 1885, p. 320 e 327).

Percebe-se que o projeto tradutório de Teixeira era oferecer versões de poetas brasileiros de poemas de Hugo em formato de livro. Alguns poemas já eram conhecidos do público brasileiro, pois já haviam sido publicados em jornais e livros de poetas nacionais; outros, porém, eram inéditos. O livro foi dedicado a Jeanne, neta de Victor Hugo e, além dos poemas, trazia uma biografia do poeta, a tradução de uma carta de Hugo aos brasileiros, notas explicativas a respeito das traduções que compunham a obra e também um poema de Lecomte de Lisle em homenagem a Hugo, traduzido por Múcio Teixeira.

Após Hugonianas, ${ }^{9}$ há em 1933 a publicação da Antologia de tradutores, organizada por Olegário Mariano, com cinco poemas de Victor Hugo junto a poemas de outros autores célebres; e também em 1950 a Antologia de poetas franceses, organizada por

\footnotetext{
${ }^{8}$ De início Múcio Texeira chega a dizer que a ideia da obra não é sua, mas em sua biografia - $O$ imperador visto de perto de 1917 - menciona que, não tendo dinheiro para financiar essa empreitada, pede auxílio a $\mathrm{D}$. Pedro II que apoia financeiramente a publicação de Hugonianas (Rouanet, 2003).

9 Após Hugonianas, encontramos em nossas leituras À memoria do immortal Victor Hugo (homenagem do Paraná), obra lançada em Curitiba em 1887. Ela é mencionada como uma das últimas publicações da casa Laemmert \& C. no jornal A instrucção pública de 14/10/1887 e também aludida por Carneiro Leão (1960, p. 254) como "um folheto no qual há trabalhos em prosa e verso, celebrando as glórias do grande homem". Todavia, não a mencionamos em nossa historiografia dos poemas traduzidos de Victor Hugo como uma obra que tenha versões poéticas hugoanas porque as informações encontradas não nos dão pistas concretas sobre o assunto.
} 
R. Magalhães Junior, com 23 poemas de Hugo somados a outros poemas franceses que compreendiam os séculos XV a XX. Embora essas duas antologias tenham outros poemas que não somente os de Hugo, elas são representativas por oferecerem ao público brasileiro, em formato de livro, a poesia hugoana em português.

Na década de 1950, obras importantes concernentes à poesia do autor francês são lançadas no Brasil: Versões poéticas brasileiras de Victor Hugo, Victor Hugo no Brasil, Obras completas de Victor Hugo e Victor Hugo: cartas, teatro e poesia.

Versões poéticas brasileiras de Victor Hugo, de C. Tavares Bastos, foi publicado em 1952 como uma edição comemorativa do $150^{\circ}$ aniversário de nascimento do poeta francês. A obra é basicamente uma pesquisa historiográfica dos poemas de Hugo e seus tradutores até aquele período (1950). Segundo Bastos, Hugonianas é

subsídio importante para o estudo da assinalada influência que sobre a poesia brasileira exerceu durante largo tempo o poeta das Contemplações, ressente-se, entretanto, o trabalho em apreço de um grave defeito: não menciona, quanto à maioria das composições extraídas de obras ou periódicos, os nomes destes e as respectivas datas de publicação, nem se refere às próprias obras onde se encontram os textos originais, referência essencial para um pronto cotejo com as versões brasileiras, cuja exatidão se torna difícil de apreciar.

Empenhado há vários anos na organização de um inventário, tanto quanto possível completo, de todas as tentativas de vernaculização de obras poéticas estrangeiras por poetas brasileiros, dei-me à esfalfante tarefa de proceder àquela investigação, tanto mais ingrata quanto frequentes são as invenções de título para poesias que não os têm no original ou, ainda, a modificação e supressão arbitrárias desses títulos [...] (Bastos, 1952, p.7)

Ou seja, a obra Versões poéticas brasileiras de Victor Hugo teve por objetivo indicar as fontes das traduções brasileiras dos poemas de Hugo, assim como mostrar quem são seus tradutores e onde e quando tais versões poéticas foram publicadas. Para empreender tal estudo, Bastos (1952) analisou especialmente as obras Hugonianas, Antologia de Tradutores, Antologia de Poetas Franceses, além de mais algumas traduções avulsas que ele tinha encontrado de poetas-tradutores até 1952. Como resultado, Bastos (1952) concluiu que existiam à época 228 poemas de Victor Hugo traduzidos para o português do Brasil (levando em consideração também as adaptações de alguns poemas, bem como as versões de um mesmo poema hugoano feitas por mais de um tradutor); somado a isso, ele quantifica em mais de uma centena o número de poetas-tradutores dos poemas hugoanos. 
Victor Hugo no Brasil de Carneiro Leão, publicado em 1960, é uma grande pesquisa sobre as relações do autor francês com nosso país, ou melhor, sobre as influências e o impacto de Victor Hugo no Brasil tanto no âmbito das artes como da política. No que tange às poesias de Hugo, Leão (1960) menciona como elas incentivaram os poetas brasileiros na feitura de uma poesia de estética romântica, seja por meio da tradução, da imitação ou mesmo do plágio. Além disso, é nesta obra que será exposta ao público brasileiro a primeira tradução de um poema de Victor Hugo: a versão de "Madame, autour de vous" de Feuilles d'automne, feita por Maciel Monteiro e datada de 1841 (Leão, 1960, p. 130-131).

As Obras completas de Victor Hugo foram publicadas no Brasil entre 1956 e 1960 pela Editora das Américas, de São Paulo, com 44 volumes. A parte que corresponde à poesia de Victor Hugo foi totalmente publicada no ano de 1960 nos cinco últimos volumes (de 40 a 44). É a única parte da coleção inteira que dispõe de um longo prefácio, escrito por Jamil Almansur Haddad. Neste prefácio, intitulado "Um momento de Victor Hugo no Brasil: Castro Alves", Haddad discorre sobre as semelhanças entre Victor Hugo e Castro Alves, comparando suas ideias e obras poéticas; e finaliza o prefácio afirmando:

Traduções em grande parte nossas, com numerosas alheias, no entanto, temos que da parte da poesia de Victor Hugo esta editora publicará "Odes e Baladas", "Orientais", "O Papa", "A piedade suprema", "Religiões e Religião", "O burro", salvo um poema ou outro, praticamente de modo integral. Dos outros livros damos extratos. (Haddad, 1960, 172).

Podemos observar pela afirmativa de Haddad que as Obras completas de Victor Hugo não eram realmente completas. Além disso, no início dos livros de poesias traduzidas, havia a seguinte nota: "Seleção de traduções e traduções de Jamil Almansur Haddad". Ou seja, o responsável por selecionar as poesias publicadas nesses tomos foi Haddad que, aliás, traduziu a maioria e também reuniu traduções de outros tradutores como poetas ou escritores pouco conhecidos para nós atualmente.

No mesmo ano em que são publicados os tomos de poesia das Obras completas, a Editora das Américas também publica uma outra coleção intitulada Victor Hugo: cartas, teatro e poesia. Nessa coleção de apenas oito tomos, figuram as mesmas traduções das Obras completas com o mesmo prefácio de Haddad. Dois pontos chamam a atenção em ambas as publicações: (1) as partes intituladas "Variantes" que aparecem ao final de alguns livros traduzidos e onde são evidenciadas outras versões de um mesmo poema de Hugo 
feitas por tradutores diferentes, o que permitia ao leitor brasileiro comparar as versões de um mesmo poema hugoano; e, 2) o fato de alguns poemas como, por exemplo, "O Burro/L'âne", "O papa/Le pape" e "Religião e religiões/Religions et religion" terem sidos traduzidos em prosa sem rima ou métrica, descaracterizando talvez os poemas hugoanos.

Depois da década de 1950, até onde pesquisamos, não há nenhum livro contendo somente poemas hugoanos traduzidos. Há somente alguns poemas avulsos traduzidos em obras de poetas brasileiros como, por exemplo, “A uma viagem" publicado no livro Poesias completas de Gustavo Teixeira em 1959, e também as republicações de obras completas de poetas-tradutores do século XIX, como Casimiro de Abreu, Castro Alves, Gonçalves de Magalhães, Gonçalves Dias, dentre outros.

Em 1983, a Editora Record do Rio de Janeiro lança o livro Coisas do entardecer traduzido por Fernando Sabino. Esta obra faz parte da coleção "Abre-te Sésamo”, dirigida ao público infantil e, de fato, pode ser considerada apenas como um poema de Victor Hugo ilustrado pelo desenhista Patrick Couratin. Já em 2002, em comemoração ao bicentenário de morte de Victor Hugo foram publicadas três coletâneas de poemas traduzidos: Victor Hugo: dois séculos de poesia, Sátiro e outros poemas e Poésie de l'enfance/Poesia da infância.

Victor Hugo: dois séculos de poesia e Sátiro e outros poemas são ambos organizados pelos poetas Anderson Braga Horta, Fernando Mendes Vianna e José Jeronymo Rivera. O primeiro publicado em Brasília pela editora Thesaurus e o segundo, no Rio de Janeiro, pela Editora Galo Branco. Poésie de l'enfance/Poesia da infância foi organizado pelas professoras, pesquisadoras e tradutoras Zélia Anita Viviani, Marie-Hélène Catherine Torres e Noêmia Guimarães Soares, publicado em Florianópolis pela Editora da UFSC. Todas essas publicações de 2002 são bilíngues, o que torna possível o cotejo entre o texto francês e as versões brasileiras.

Dez anos depois, em 2012, encontramos apenas duas traduções de poemas de Victor Hugo: Coisas do ocaso e O ogro da Rússia. A primeira é uma tradução do linguista, escritor e poeta Marcos Bagno que vem em anexo ao texto "Choses du soir: o que se traduz quando se traduz poesia?", publicado no livro Victor Hugo: disseminações da Editora Horizonte; e a segunda é uma tradução de Eduardo Brandão direcionada ao público infantil (além de ser um poema ilustrado), publicada pela editora Companhia das Letrinhas. 
Depois dessas notas historiográficas dos poemas traduzidos de Victor Hugo, cabenos ainda falar um pouco sobre as escassas reflexões e teorizações existentes a respeito dessas traduções.

\section{Reflexões e teorizações brasileiras das traduções de poesia hugoana}

Muitos foram os tradutores de Victor Hugo no Brasil: de grandes literatos a chefe de Estado, de desconhecidos a gênios das artes no Brasil. Para citar alguns nomes mais conhecidos, dentre as traduções escritas e interartísticas, podemos mencionar: no século XIX, Gonçalves de Magalhães, Gonçalves Dias, Castro Alves, Arthur e Aluízio de Azevedo, Machado de Assis e D. Pedro II; no século XX, Raimundo Correia, Sousândrade, Villa-Lobos, Fernando Sabino; e no século XXI, Marcos Bagno e Anderson Braga Horta.

Durante o século XIX e também na primeira metade do século XX, muitos foram os comentários sobre as traduções de poemas hugoanos; todavia, em sua maior parte, essas críticas não passavam da dicotomia boa/má tradução, consequentemente, exaltando ou não o poeta-tradutor. Para além disso, percebe-se que durante todo esse período não existia ainda um consenso entre os poetas-tradutores do que realmente viria a ser a tradução poética. Alguns defendiam que a tradução poética era uma imitação ou mesmo paráfrase ${ }^{10}$ do texto fonte, visto que era difícil e complexo verter um poema hugoano (em francês) para a língua vernácula (português brasileiro) (Teixeira, 1885). Outros afirmavam que não existia de verdade "a tradução", mas sim a inspiração e a paródia oriunda do poema em francês, o que ocasionava, por vezes, plágio ou mesmo apropriação do poema completo ou de versos da poesia hugoana (Leão, 1960). A nomeação de títulos dos poemas em português brasileiro era um exemplo deste tipo de "apropriação" e foi até umas das razões que levaram Tavares Bastos a realizar a publicação do livro Versões poéticas brasileiras de Victor Hugo.

Será Carneiro Leão que, ao falar das traduções de poesias feitas por poetas brasileiros, mencionará, concretamente, uma das primeiras reflexões ou teorizações sobre a tradução de poemas hugoanos:

\footnotetext{
${ }^{10}$ Com base em Vianna (2002, p. 21), talvez possamos considerar que também é possível encontrar no século XIX o conceito de tradução como uma metaparáfrase, ou seja, "uma espécie de paráfrase com temática e versificação próprias". O poema "A tempestade" de Gonçalves Dias, por exemplo, é uma metaparáfrase de "Os Dijinns" de Victor Hugo (Vianna, 2002).
} 
Raimundo Correia nos dá, além do belo soneto atrás citado, traduções que, na concepção de Celso Vieira, "se afiguram mais aparições do poeta oráculo de Guernesey", vindo ao nosso encontro, falando em nosso idioma, com a mesma retumbância evocada de abismos tempestuosos ou a mesma reminiscência musical de arroios borbulhantes".

Não vamos buscar aí a tradução ao pé da letra, no mesmo ritmo, na mesma medida, na mesma ordem, mas a transfusão do sentimento, da emoção, do pensamento, com vigor análogo, metáforas semelhantes, a nos ressuscitar Hugo em seus ímpetos e em suas aleluias. (1960, p. 52)

É deliciosa a doçura dos versos de Hugo, magistralmente transfundidos para a nossa língua quer na tradução, quer na reminiscência de Vicente de Carvalho. (p. 139)

A versão brasileira é magistral na fidelidade e na doçura das expressões e dos acentos encontrados pelo nosso poeta.

Agora examinemos este milagre de transfusão do francês para o português, realizado por Castro Alves [...] (p. 151)

É uma página de singular beleza e harmonia. É de ver a felicidade com que Castro Alves usa os mesmos símbolos, e nos retrata a mesma emoção, servindo-se de imagens equivalentes e de metáforas de pujança análoga. (p. 153)

As traduções são excelentes. Parece até que a interrogação final da poesia nos dá angústia ainda maior nas traduções de Artur Azevedo e de Cassiano Tavares Bastos do que no original. [...] As traduções interpretam com nitidez e, às vezes, palavra por palavra, o fato e o sentimento expressos no original. [...] Ambas nos provam a fonte maravilhosa de inspiração que foi, que é Victor Hugo, se êle persiste em nosso meio, em nossa língua, manancial inesgotável para criações felizes! (p. 161)

Percebemos nessa reflexão que Carneiro Leão enuncia um método de tradução poética: a transfusão. Técnica que consiste na não-busca por palavra-por-palavra, nãobusca pela mesma rima ou mesma melodia, mas sim na busca pelas mesmas emoções que o poema produz em francês, pelo viés da interpretação. Lembramos que transfusão, segundo o dicionário Houaiss, tem por primeira acepção a "passagem de um líquido de um vaso a outro" e por segunda acepção a "transformação em outro". Assim, Carneiro Leão talvez concebesse a tradução de poesia hugoana como um misto de passagem, transformação e criação.

Outra reflexão nos é dada em 2002, na introdução da obra Poésie de l'enfance/Poesia da infância, escrita pelas tradutoras Zélia Anita Viviani, Marie-Hélène Catherine Torres e Noêmia Guimarães Soares. Nas palavras delas, "todo ato tradutório é, por um lado, um ato de comunicação intercultural e, por outro lado, uma re-criação de um sentido possível no texto de origem em outro texto - o texto traduzido" (Hugo 2002, p. 
18). Segundo elas, traduzir um texto poético como o de Hugo é manter o equilíbrio entre ideia e ritmo, respeitar a estética do poema. Mesmo com esse posicionamento, as tradutoras admitem não ter conseguido respeitar o ritmo original da poesia hugoana e nos falam de suas dificuldades:

Tentamos respeitar a estética de cada poema, buscando principalmente a rima e a métrica do texto do autor, embora nem sempre tenhamos conseguido traduzir o ritmo original. Este foi um dos maiores desafios que encontramos, pois Victor Hugo, como se sabe, foi um dos grandes mestres dos alexandrinos. [...]

Não somente os alexandrinos se nos apresentaram como um grande desafio, mas também os poemas sob forma de "cirandas" [...] Talvez a dificuldade de traduzi-los tenha sido até mesmo maior do que a da tradução dos alexandrinos, devido à preocupação em mantermos o ritmo, já que se trata de "canções", cuja cadência assemelha-se àquela das cantigas de roda, próprias para dançar. (2002, p. 18-19)

Em suma, as tradutoras, diante das dificuldades com os alexandrinos e, sobretudo, com as cirandas, entendem a tradução dos poemas de Hugo como um ato de contextualização tradutória em que não se traduz somente língua, mas sim uma cultura para outra cultura.

Anderson Braga Horta, em um ensaio de 2012 intitulado "Poesia hugoana em tradução", nos conta como foi sua experiência de traduzir Hugo junto aos seus amigos e poetas Fernando Vianna e José Rivera. Além disso, escreve sobre sua postura diante da tradução poética:

Creio que há, basicamente, duas maneiras de traduzir poesia em geral. A primeira, a mais óbvia, e menos ambiciosa, é limitar-se à tradução dita literal, adstrita quase aos aspectos semânticos-sintáticos do texto. $O$ tradutor, nessa modalidade, se resigna a perder conotações, o ritmo, a melodia da frase, se não a cor das imagens. O jogo, a dança das palavras. A segunda, mais ambiciosa, procura recriar na língua-meta a capacidade encantatória do verso original, ainda que ao preço de alguma substância perdida naqueles estratos semânticos-sintáticos, não raro tendo de substituir imagens, cortar detalhes, acrescentar algo.

[...]

Quando comecei a me interessar pela tradução de poesia, tinha já meus sete anos de pastor em metro e rima, de forma que me orientei naturalmente para a modalidade recreativa. De notar que a recriação de que falamos não implica nenhuma liberdade absoluta em face do original; pelo contrário, exige a busca da maior fidelidade possível a cada um dos estratos do poema a traduzir (Horta, 2012, p. 338-339). 
Horta elucida que sua tradução de poemas hugoanos foi recreativa e que tal maneira de traduzir alcança todos os estratos da poesia de Victor Hugo: conotações, melodia, ritmo, cor das imagens, capacidade encantatória. Para ele, ao se traduzir Hugo é preciso "recombinar, em português, na caixa do alexandrino" (p. 339) e "reproduzir a melodia da narrativa e, mais que tudo, imitar o brilho da prestigiosa imagem" (p. 341) que há em cada poema hugoano.

No mesmo livro em que foi publicado o texto anteriormente referido de Braga Horta, também foi publicado o texto de Marcos Bagno denominado "Choses du soir: o que se traduz quando se traduz poesia?". Este artigo de Bagno explicita sua teoria da tradução poética tendo por base sua experiência tradutória do poema Choses du soir. Segundo ele, ao se traduzir um poema (seja de Hugo ou não) se traduz: a substância fônica, o ritmo, a iconicidade, o gênero, o estilo, o horizonte de interlocução e o discurso. Em especial, comparando sua tradução de Choses du soir com a tradução de Fernando Sabino publicada em 1983, Bagno (2012) chama a atenção para o discurso, o ritmo e a sonoridade do poema:

Se o par indissociável ritmo/oralidade compõe o cerne da tradução de uma obra literária, com mais forte razão deveria ser observado na tradução de um poema como "Choses du soir", em que ritmo/oralidade atingem o estatuto de pura música. [...]

A tradução de Fernando Sabino é praticamente "literal", mas a literalidade não pode preponderar sobre a literariedade, sobre o ritmo e a musicalidade dos versos. Somente quando a métrica e/ou a rima impedem é que sua tradução opta por fazer "adaptações", afastando-se, sempre o mínimo possível, do "conteúdo original". No entanto, retomando as palavras de Meschionnic, é preciso abandonar a ideia de traduzir "língua" em proveito da tradução do discurso, e o discurso poético é essencialmente ritmo, oralidade, sonoridade (p. 349 e 351$)$.

Isto é, para Bagno o poema hugoano é extremamente musical porque tem ritmo e sonoridade própria. Somado a isso, segundo ele, o poema de Hugo também é um discurso singular qualificado por critérios eminentemente socioculturais que o caracterizam como um texto poético-literário.

Unindo todas as reflexões e teorizações mencionadas, percebemos que traduzir um texto poético de Hugo vai muito além das transposições linguísticas porque não é meramente a dicotomia forma/conteúdo que está por trás dele, mas a força e a voz do poeta ritmadas e oralizadas na transmissão de um enunciado escrito único. 


\section{Conclusão}

Após termos discorrido sobre as traduções de poemas de Victor Hugo no Brasil, concordamos sensatamente com a afirmativa do proêmio do livro Victor Hugo: dois séculos de poesia escrita pelo seu editor: "Parece-nos que a sua imensa obra poética não tem merecido a mesma atenção" (Hugo, 2002, p. 9).

O editor, ao fazer tal afirmativa, aponta o mesmo caminho que concluímos neste trabalho: existem (e existiram) no Brasil traduções completas dos romances, das peças teatrais, das cartas, dos discursos políticos de Victor Hugo; só ainda não há (e não houve) a publicação de um livro de poesia completo do autor. Até mesmo as traduções de Jamil Haddad e outros tradutores feitas nas chamadas Obras completas de 1960 não são livros de obras poéticas completas de Victor Hugo, pois o tradutor afirmar que falta entre as obras publicadas "um poema ou outro".

Dos poemas de Hugo traduzidos no Brasil, desde o século XIX até os dias atuais, foram priorizados pelos tradutores aqueles que de alguma maneira compartilhavam o pensamento literário deles. E ao se identificar com um ou mais poemas hugoanos, isso não significava o comprometimento com uma obra poética completa, o que talvez justifique a publicação no Brasil de antologias e coletâneas de poesias de Victor Hugo em detrimento de livros na íntegra.

Quanto às reflexões e teorizações a respeito da poesia de Hugo, seja em francês ou mesmo traduzida, elas ainda são incipientes. Victor Hugo não é considerado ainda pela crítica literária um grande poeta, apesar de sua obra monumental e de sua grande influência no Brasil. Essa situação foi debatida em forma de protesto pelo poeta e tradutor Fernando Vianna na introdução do livro O sátiro e outros poemas, publicado em 2002.

O presente trabalho faz um levantamento dos poemas de Victor Hugo que foram traduzidos no Brasil, sobretudo até a década de 1960. A pequena proporção dessas traduções mostra, talvez, o quanto a poesia de Hugo ainda não é tão valorizada em solo nocional, diante das escassas traduções que foram feitas da década de 1970 até os dias atuais.

\section{Referências bibliográficas:}


BAGNO, M. Choses du soir: o que se traduz quando se traduz poesia? In: BARRETO, (org)., 2012.

BARRETO, J. (org). Victor Hugo: disseminações. Vinhedo: Editora Horizonte, 2012.

BASTOS, C. Versões poéticas brasileiras de Victor Hugo. Petrópolis: Rio de Janeiro, 1952.

CERTEAU, M. A escrita da História. Trad. Maria de Lourdes Menezes. Rio de Janeiro: Forense, 1982.

CORREIO DO BRASIL. Bahia, 1903. Semanal.

D'HULST, L. Why and how to write translation histories?. In: Revista Crop, São Paulo, v. 6, p. 21-32, 2001. Disponível em: $\langle$ http://200.144.182.130/revistacrop/images/stories/edicao6/v06a03.pdf $>$. Acesso em 28/10/13.

EL CORREO GALLEGO. Rio de Janeiro, 1904. Semanal.

GAZETA DO NORTE. Ceará, 1881. Semanal.

HADDAD, J. Um momento de Victor Hugo no Brasil: Castro Alves. In: HUGO, 1960.

HORTA, A. Poesia hugoana em tradução. In: BARRETO (org), 2012.

HOVASSE, J-M. Victor Hugo I. Avant l'exil (1802-1851). Paris: Fayard, 2001.

HUGO, V. Obras completas. Tomo 40. Editora das Américas: São Paulo, 1960.

. Euvres poétiques complètes. Réunies et présentées par Francis Bauvet. Paris: Jean-Jacques Pauvert Éditeur, 1961.

. O sátiro e outros poemas. Trad. Anderson B. Horta; Fernando M. Vianna; José J. Rivera. Galo Branco: Rio de Janeiro, 2002.

. Poésie de l'enfance/Poesia da infância. Trad. Zélia Viviani, Marie-Hélène Torres, Noêmia Soares. Editora UFSC: Florianópolis, 2002.

JUIN, Hubert. Victor Hugo. Paris: Flammarion, 1980-1986.

LASTER, A. Victor Hugo, hoje e amanhã. In: BARRETO (org), 2012.

LEÃO, A. C. Victor Hugo no Brasil. José Olympio: Rio de Janeiro, 1960.

MAGALHÃES JUNIOR, R. Antologia de poetas franceses. Gráfica Tupi Ltda: Rio de Janeiro, 1950.

MARIANO, O. Antologia de Tradutores. Guanabara: Rio de Janeiro, 1933. 
MESCHONNIC, H. Écrire Hugo. Pour la poétique IV. Paris: Gallimard, 1977.

O IMPARCIAL. Rio de Janeiro, 1922. Semanal.

O MEQUETREFE. Rio de Janeiro, 1881. Semanal.

REVIST A KOSMOS. Rio de Janeiro, 1904. Semanal.

ROUANET, S. Prefácio. In: TEIXEIRA, M. (org.). Hugonianas. $3^{\text {a }}$ ed. Rio de Janeiro: Academia Brasileira de Letras, 2003.

TEIXEIRA, M. Hugonianas. Impressa Nacional: Rio de Janeiro, 1885. Disponível em: <http://objdigital.bn.br/acervo_digital/div_obrasgerais/drg275012/drg275012_item1 /P1.html>. Acesso em 27/10/13.

TORRES, L. O conceito de história e historiografia. In: BIBLOS - Revista do Instituto de Ciências Humanas e da Informação, Rio Grande, v. 8, 53-59, 1996.

VIANNA, F. Victor Hugo: duzentos anos de poesia. In: HUGO, 2002.

VIVIANI, Z.; TORRES, M-H.; SOARES, N. Apresentação. In: HUGO, 2002. 